\title{
Managing Nitrogen for High Corn Yields ${ }^{1}$
}

John E. Sawyer

Associate Professor

Department of Agronomy

Iowa State University

\section{Introduction}

The old saying still holds; yield is king. Producers are interested in high crop yields in order to pay for input costs, cover enterprise expenses, and provide profits. Demand for corn grain is increasing rapidly, with large need for expanding ethanol and livestock production. This demand is fueling interest in higher productivity and more continuous corn (CC). Yields are now commonly topping 200+ bu/acre, and risk of yield loss related to nitrogen (N) management weighs as heavily on the minds of producers as it ever has. What $\mathrm{N}$ management practices make sense to sustain high yield in corn following soybean, and in continuous corn, while at the same time considering economic return and water quality issues.

\section{Nitrogen Rate}

Nitrogen fertilization rate has historically been based on expected economic return from yield increase to applied $\mathrm{N}$. The recently developed regional approach to $\mathrm{N}$ rate guidelines (Concepts and Rationale for Regional N Rate Guidelines for Corn; Sawyer et al., 2006) uses N and corn prices to determine a $\mathrm{N}$ rate that produces maximum return to $\mathrm{N}$ (MRTN). The basis for the MRTN rate is the yield increase from $\mathrm{N}$ application, minus the $\mathrm{N}$ fertilizer cost. An example of this net return for corn following soybean (SC) and CC is shown in Figure 1, determined from many $\mathrm{N}$ rate response trials conducted across Iowa in recent years. The MRTN rate and range of similar profitability is derived from an accumulation of responses for all trials. Since we must predict into an unknown future what $\mathrm{N}$ rate to apply, the response trials provide guidance as to the potential outcome based on past experience. Yield response (yield increase to $\mathrm{N}$ application) directly determines optimal application rate. Since yield level is not directly related to optimal N fertilization rate, harvested yield (realistic yield potential attainable yield) is not used in the MRTN calculation. This causes considerable concern with producers and crop advisers. The expectation is that higher yields require higher fertilization rate. However, this has not been the case. Instead, it is the yield increase from $\mathrm{N}$ application, along with corn and $\mathrm{N}$ prices, that determines optimal $\mathrm{N}$ rates.

A pertinent question is: are highly productive sites included in the $\mathrm{N}$ rate response trials, and what would be the $\mathrm{N}$ fertilization requirement if only high yield sites (200+ bu/acre) are used to derive an economic optimum $\mathrm{N}$ rate? This question can be answered several ways. First; group the $\mathrm{N}$ response trials into yield categories. That is, what would be the MRTN rate for those sites with yields less than 150 bu/acre, yields from 150-200 bu/acre, and yields greater than 200 bu/acre. For SC in Iowa, the MRTN rate is within $2 \mathrm{lb}$ N/acre (126-128 lb N/acre) across these yield ranges. For CC the MRTN rate varies somewhat between yield ranges; the MRTN rate is $156 \mathrm{lb}$ N/acre for sites with yields less than $150 \mathrm{bu} / \mathrm{acre}$; and $189 \mathrm{lb}$ N/acre for yields at 150-200 bu/acre and yields greater than 200 bu/acre. From these yield ranges, there is no consistent

\footnotetext{
${ }^{1}$ Presented at the 2006 Integrated Crop Management Conference. November 29-30, 2006, p. 191-199. Iowa State University, Ames, IA.
} 
evidence that highest yielding sites require a higher $\mathrm{N}$ fertilization rate. Second; a more sitespecific approach would be to look at the economic optimum $\mathrm{N}$ rate (EONR) for individual sites. Sites with high yields (greater than 220 bu/acre) from various $\mathrm{N}$ rate trials conducted recently in Iowa are listed in Table 1, along with the EONR, yield at the EONR, and maximum yield. These EONR's are typical of those found for the two rotations, and do not indicate a high $\mathrm{N}$ rate need because of an exceptionally high yield. Third; look at the EONR graphed against grain yield for many sites. This graph is shown in Figure 2 for SC. The EONR's for the highest yielding sites are not higher than those for lower yielding sites, and there is no statistical relationship between EONR and yield (note the scatter of points). Variation exists in EONR between sites, but that is not dictated by yield. Fourth, compare $\mathrm{N}$ rates needed to optimize yields over time. Corn yields have increased, but study of $\mathrm{N}$ response data from long-term studies (20 years or more) does not indicate a change in optimal $\mathrm{N}$ rates or that optimal rates are higher today. Comparison of the profitable $\mathrm{N}$ rate ranges for SC and CC derived from the recent Iowa data (at the 0.10 price ratio, is 110-145 lb N/acre for SC and 160-200 lb N/acre for CC; Figure 1 and Table 2) with the suggested N rate ranges from a 1979 extension publication (100-150 lb N/acre for SC and 150$200 \mathrm{lb}$ N/acre for CC; Voss and Shrader, 1979) shows a similarity in N fertilization need across many years in Iowa.

Bottom line, $\mathrm{N}$ rates do not need to change for situations with high yields. The amount of plantavailable $\mathrm{N}$ supplied from the soil system tends to increase when climatic conditions are conducive for high yields, root exploration of the soil increases, and the crop is more efficient at utilizing available $\mathrm{N}$; thus there is compensation for the increased plant $\mathrm{N}$ demand at high yield not met by fertilizer application. The soil system supplies approximately 60 to $75 \%$ of corn $\mathrm{N}$ requirements, with the remainder from fertilization. Therefore, variation in soil supply can easily accommodate varying plant requirements and disrupts a direct relationship between yield and fertilization need. Also, $\mathrm{N}$ fertilization is important to enable high productivity, but corn yield levels are largely dictated by adequate moisture. Rate decisions based on economic return to N, corn price, and $\mathrm{N}$ fertilizer price through the web based Corn $N$ Rate Calculator will be appropriate for high yield situations, as they are for other production levels. Attempting to ensure adequate $\mathrm{N}$ or high yields through application of rates well above economic optimum leads to reduced net return, with especially negative consequences at high $\mathrm{N}$ prices and low corn prices (Figure 1). Concurrently, nitrate losses through leaching and tile flow increase at $\mathrm{N}$ rates above optimum.

\section{Nitrogen Rate and Tile Flow Nitrate}

Unfortunately, application of $\mathrm{N}$ for corn production results in an increase in nitrate moving from fields (example for tile drainage in Figure 3). This loss occurs even with no $\mathrm{N}$ application, but does increase with increasing $\mathrm{N}$ rate. From no $\mathrm{N}$ to approximately the optimal rate, the nitrate- $\mathrm{N}$ concentration increases slowly, but above the optimal rate it can increase at a faster rate.

Therefore, $\mathrm{N}$ application at rates well above optimum not only result in less profit (Figures 1 and 3 ), but also result in increased nitrate loss. Therefore, beyond economic incentive, there is an environmental incentive to match $\mathrm{N}$ fertilization rate to corn need. Within the $\mathrm{N}$ rate range providing similar profitability (Figure 1), applying $\mathrm{N}$ in the lower part of the range should increase $\mathrm{N}$ use efficiency as well as help minimize nitrate loss. Risk of $\mathrm{N}$ being short, however, does increase at use rates in the lower part of the range. 


\section{Continuous Corn and Corn in Rotation with Soybean}

The required $\mathrm{N}$ fertilization rate is higher when corn follows corn than following soybean. For many years this was called the "soybean credit", implying that soybean plants left unused $\mathrm{N}$ in the soil. That was a misperception. It is true that the $\mathrm{N}$ fertilization rate is less for SC than CC, but the reasons are related to amount of residue and $\mathrm{N}$ content, timing of residue decomposition, and mineralization rate of organic matter. From a soil resource standpoint, soybean actually results in a net $\mathrm{N}$ removal. While the reasons for the $\mathrm{N}$ fertilization rate difference are interesting, the bottom line is that more $\mathrm{N}$ fertilizer is required with $\mathrm{CC}$ than SC.

There are different ways to look at corn fertilization needs in different rotations. First; simply determine corn yield increase and economic response to $\mathrm{N}$ rate in each rotation, that is, calculate the maximum return rate (MRTN) for each rotation. For Iowa, those rates are shown in Figure 1 and Table 2 for CC and SC. At a $0.10 \mathrm{~N}$ :corn price ratio, the MRTN rates are $179 \mathrm{lb}$ N/acre for $\mathrm{CC}$ and $123 \mathrm{lb}$ N/acre for SC. The rate difference is $56 \mathrm{lb} \mathrm{N} /$ acre. The MRTN rates for each rotation can be determined for different price ratios using the web based Corn $N$ Rate Calculator. Second; determine $\mathrm{N}$ responses from split-plot studies that directly compare corn in each rotation. Using data from studies conducted at seven ISU farms from 2000-2005 (Figure 4), the $\mathrm{N}$ fertilization rate difference is $59 \mathrm{lb} \mathrm{N} / \mathrm{acre}$. This is basically the same rate difference as determined using the database in the Corn $N$ Rate Calculator.

\section{Multiple Years of Corn and Corn Following Various Crops}

This topic will be thoroughly discussed in another Integrated Crop Management Conference report by A.P. Mallarino and E. Ortiz-Torres. Data from the Nashua site (Figure 5) show that for second and third year corn following soybean (c-C-s; c-C-c-s; c-c-C-s), the $\mathrm{N}$ fertilization rate is the same as continuous corn (C-C). This means that the rotation effect for soil $\mathrm{N}$ supply is gone after one corn year. For first year corn following soybean, either soybean every-other-year (C-s), or one year of soybean after multiple years of corn (C-c-s; C-c-c-s), or second year corn following alfalfa (c-C-a-a), the $\mathrm{N}$ rate response is the same as corn in a C-s rotation.

\section{Application Timing and Products}

To receive the full potential yield increase, to obtain the greatest economic return possible, and to provide the opportunity for high yields from applied $\mathrm{N}$, fertilizers should be managed to avoid losses and to provide adequate available $\mathrm{N}$ within the root zone when the plant requires it. This means matching products with the appropriate timing and placement. The following information gives suggested $\mathrm{N}$ fertilizer management for corn based on general Iowa climatic conditions, fertilizer properties, placement, and probability for loss through leaching, denitrification, and volatilization.

For fall $\mathrm{N}$ fertilizer application, the only product suggested is anhydrous ammonia. If that application is made, it should be in the late fall after soils have cooled (below $50^{\circ} \mathrm{F}$ and continued cooling), and the colder the better. A nitrification inhibitor can be used to further slow nitrification. Products like UAN (28 or 32\% urea-ammonium nitrate solution), ammonium sulfate, urea, and ammonium nitrate should not be fall applied. Spring preplant, split preplant/sidedress, and sidedress applications will provide similar results on many Iowa soils. Products containing nitrate should be applied close to planting or sidedress. Coarse textured soils, soils underlain with fractured bedrock, and soils with high probability for flooding, poor 
drainage, or excessive wetness have suggested $\mathrm{N}$ applications more toward sidedressing or split preplant/sidedress. Urea and UAN solutions should be incorporated or injected into the soil to avoid volatile losses (within 2-3 days of application). A urease inhibitor can help slow volatilization when surface applied and not incorporated, especially wit high residue cover. Surface or shallow placed sidedress $\mathrm{N}$ may be positionally unavailable if rain is not received to move the fertilizer into the root zone, thus limiting response to the applied $\mathrm{N}$.

New controlled-release urea products, like ESN (polymer-coated urea) manufactured by Agrium, Inc., are showing promise for improving urea performance when spring preplant incorporated. To date, five years of research conducted in Iowa (Northern and Northwest research farms located at Kanawha and Sutherland) with ESN indicates a 6 bu/acre average yield increase compared to urea when spring applied (incorporated), but not a reduction in required $\mathrm{N}$ rate (Moore et al., 2006). This means the ESN improves urea performance, but does not result in a lower $\mathrm{N}$ fertilization requirement. Three years of research conducted in Iowa with fall application (Moore et al., 2006) indicates that ESN provided an average 4 bu/acre yield increase compared to fall urea, but had a 4 bu/acre lower yield compared to spring urea (and an 8 bu/acre yield difference between fall and spring urea). That research continues to evaluate if yield improvement will pay for the additional material cost, and comparison with other fertilizer products.

With continuous corn, and no-tillage corn, having a supply of available $\mathrm{N}$ is helpful for early growth and high productivity. For planned sidedress applications, some $\mathrm{N}$ should be applied preplant or as starter with the planter. This rate should be large enough to carry the plant to sidedress time. Several studies in the Midwest have shown that 20-30 lb N/acre as starter $\mathrm{N}$ improves no-tillage corn yield. This rate is more $\mathrm{N}$ than can be placed safely with the seed, so preplant application or starter placed away from the seed is needed. In high residue systems, like continuous corn, and especially no-tillage corn, placing $\mathrm{N}$ fertilizer products below the soil surface avoids contact with crop residue, eliminates volatile losses, and improves performance and yield.

With high corn yields, corn residue levels have increased and can sometimes be challenging to manage. Producers have questioned whether adding $\mathrm{N}$ in the fall and chopping residue will speed decomposition. These questions were studied in a three-year no-till corn project by Dr. Larry Bundy at the University of Wisconsin (information available at http://www.soils.wisc.edu/extension/teachingmaterials/Napplication_residue_decomp/Napplicati onpage.htm). Residue was either chopped or not chopped, and $\mathrm{N}$ was applied as ammonium sulfate or $28 \%$ UAN solution to corn residues in November at $30 \mathrm{lb}$ N/acre. Other $\mathrm{N}$ treatments included $100 \mathrm{lb}$ N/acre as ammonium sulfate in the fall and spring, and various combinations of spring and fall $\mathrm{N}$ to provide a total of $190 \mathrm{lb}$ N/acre. Results showed that time of application, source of $\mathrm{N}$, and residue chopping did not affect $\mathrm{N}$ mineralization, soil temperature, or rate of residue decomposition. Fall $\mathrm{N}$ applications to promote corn residue decomposition did not improve no-till corn yields, with volatile and over-winter $\mathrm{N}$ loss and lower $\mathrm{N}$ availability (lower yield) found in some years. Little corn residue decomposition occurred in the fall (because of cold soils), with about $60-70 \%$ of residue decomposed during the subsequent growing season (when soils are warm). Application of fall $\mathrm{N}$ to corn residue as a means to speed decomposition and increase yield does not appear justified. 


\section{Additional Information}

The regional N rate publication Concepts and Rationale for Regional N Rate Guidelines for Corn is available for order from the ISU University Extension online store at https://www.extension.iastate.edu/store/ListItems.aspx?Keyword=2015, and on-line for download in PDF format at http://www.extension.iastate.edu/Publications/pm2015.pdf.

The web based tool Corn Nitrogen Rate Calculator is based on the MRTN guideline approach. It calculates the MRTN rate, profitable $\mathrm{N}$ rate range, net return to $\mathrm{N}$, percent of maximum yield, $\mathrm{N}$ product rate and cost, and other information directly from $\mathrm{N}$ response trial databases for Illinois, Iowa, Minnesota, and Wisconsin. Calculations can be computed for CC or SC, and can be compared with up to four sets of $\mathrm{N}$ fertilizer and corn prices. This calculator is located at http://extension.agron.iastate.edu/soilfertility/nrate.aspx. This fall, $\mathrm{N}$ response trial databases have been updated, and specific fertilizer products can be chosen with $\mathrm{N}$ price based on $\$ / \mathrm{lb} \mathrm{N}$ or product cost.

\section{References}

Mallarino, A.P., E. Ortiz-Torres, and K. Pecinovsky. 2005. Effects of crop rotation and nitrogen fertilization on crop production. In annual progress reports-2005. Northeast research and demonstration farm. ISRF04-13. Iowa State Univ., Ames, IA. http://www.ag.iastate.edu/farms/reports.html.

Moore, J., R. Killorn, and M. Gonzalez. 2006. Corn yield response to fall and spring applied controlled-release urea vs. spring conventional urea. p. 101-105. In Proc. N. C. Ext.-Ind. Soil Fertility Conf., Des Moines, IA. 7-8 Nov., 2006. Vol. 22. Potash and Phosphate Inst., Brookings SD.

Nafziger, E.D., J.E. Sawyer, and R.G. Hoeft. 2004. Formulating N recommendations in the corn belt using recent data. p. 5-11. In Proc. Thirty-Fourth North Central Extension-Industry Soil Fertility Conf., Des Moines, IA. 17-18 Nov. 2004. Vol. 20. Potash \& Phosphate Inst., Brookings, SD.

Sawyer, J.E., and E.D. Nafziger. 2005. Regional approach to making nitrogen rate decisions for corn. p. 16-24. In Proc. Thirty-Fifth N. C. Ext.-Ind. Soil Fertility Conf., Des Moines, IA. 16-17 Nov. 2005. Vol. 21. Potash \& Phosphate Inst., Brookings, SD.

Sawyer, J., E. Nafziger, G. Randall, L. Bundy, G. Rehm, and B. Joern. 2006. Concepts and Rationale for Regional Nitrogen Rate Guidelines for Corn. PM 2015. Iowa State Univ. Ext., Ames, IA.

Sawyer, J.E., and G.W. Randall. 2005. Nitrogen rates, p. 59-71. In Proc. Gulf Hypoxia and Local Water Quality Concerns Workshop, Ames, IA. 26-28 Sep. 2005. Upper Mississippi Subbasin Hypoxia Nutrient Committee, Iowa State Univ., Ames, IA.

Voss, R.D., and W.D. Shrader. 1979. Crop rotations-effect on yields and response to nitrogen. Publication pm-905 (out of print). Iowa State Univ. Ext., Ames, IA. 
Table 1. Economic optimum $\mathrm{N}$ rate (EONR) for $\mathrm{N}$ rate trial sites in Iowa with maximum corn yield greater than $220 \mathrm{bu} / \mathrm{acre}$.

\begin{tabular}{|cccc|}
\hline Previous Crop & EONR & Yield at EONR & $\begin{array}{c}\text { Yield at Maximum } \\
\text { N Response }\end{array}$ \\
\hline Soybean & lb N/acre & ----- - bu/acre ----- \\
Soybean & 131 & 219.9 & 221.2 \\
Soybean & 75 & 223.5 & 223.7 \\
Soybean & 145 & 228.6 & 228.6 \\
Soybean & 163 & 227.9 & 229.0 \\
Soybean & 110 & 232.2 & 232.8 \\
Soybean & 119 & 235.5 & 236.1 \\
Soybean & 118 & 236.5 & 237.0 \\
Soybean & 133 & 237.9 & 239.0 \\
Soybean & 151 & 239.3 & 240.3 \\
Soybean & 101 & 240.6 & 241.4 \\
Soybean & 112 & 241.4 & 241.8 \\
Soybean & 67 & 246.1 & 241.9 \\
Corn & 123 & 229.9 & 246.4 \\
Corn & 196 & 231.0 & 231.0 \\
Corn & 140 & 231.5 & 231.7 \\
Corn & 126 & 241.9 & 231.8 \\
EONR at 0.10 N:corn price ratio (\$lb N:\$bu corn). & 242.3 \\
\hline \multicolumn{4}{|c}{} \\
\hline
\end{tabular}

Table 2. Suggested $\mathrm{N}$ fertilizer application rates for corn following soybean (SC) and continuous corn (CC) in Iowa.

\begin{tabular}{|c|c|c|c|c|}
\hline \multirow{3}{*}{$\begin{array}{c}\text { Nitrogen ra } \\
\text { Price } \\
\text { Ratio }^{1} \\
\end{array}$} & & ent 1 & \multirow{2}{*}{\multicolumn{2}{|c|}{ Corn Following Corn }} \\
\hline & \multicolumn{2}{|c|}{ Corn Following Soybean } & & \\
\hline & Rate $^{2}$ & Range $^{3}$ & Rate & Range \\
\hline$\$ / l b: \$ / b u$ & \multicolumn{4}{|c|}{ - } \\
\hline 0.05 & 145 & $126-169$ & 205 & $184-237$ \\
\hline 0.10 & 23 & $108-144$ & 179 & $158-201$ \\
\hline 0.15 & 110 & $94-126$ & 155 & $140-176$ \\
\hline 0.20 & 96 & $83-112$ & 143 & $126-158$ \\
\hline \multicolumn{5}{|c|}{$\begin{array}{l}1 \text { Price per lb } \mathrm{N} \text { divided by the expected corn price. For example, } \mathrm{N} \text { a } \\
\$ 0.25 / \mathrm{lb} \mathrm{N} \text { and corn at } \$ 2.50 / \mathrm{bu} \text { is a } 0.10 \text { price ratio. }\end{array}$} \\
\hline \multicolumn{5}{|c|}{$\begin{array}{l}{ }^{2} \text { Rate is the } \mathrm{lb} \text { N/acre that provides the maximum return to } \mathrm{N} \\
\text { (MRTN). All rates are based on results from the Corn N Rate } \\
\text { Calculator as of Sept. 1, } 2006 \\
\text { (http://extension.agron.iastate.edu/soilfertility/nrate.aspx). }\end{array}$} \\
\hline \multicolumn{5}{|c|}{$\begin{array}{l}{ }^{3} \text { Range is the range of profitable } \mathrm{N} \text { rates that provides a similar } \\
\text { economic return to } \mathrm{N} \text { (within } \$ 1.00 \text { /acre of the MRTN). }\end{array}$} \\
\hline
\end{tabular}


Figure 1. Net return to $\mathrm{N}$ fertilizer application for 129 corn following soybean (SC) sites and 64 continuous corn (CC) sites in Iowa at four N:corn price ratios (corn held constant at $\$ 2.20 / \mathrm{bu}$ and $\mathrm{N}$ prices at $\$ 0.11, \$ 0.22, \$ 0.33$, and $\$ 0.44 / \mathrm{lb} \mathrm{N}$ result in price ratios of $0.05,0.10,0.15$, and 0.20 ). The closed symbol on each line represents the MRTN rate for that price ratio, and the open symbols represent the profitable $\mathrm{N}$ rate range within $\$ 1.00$ /acre of the maximum return.
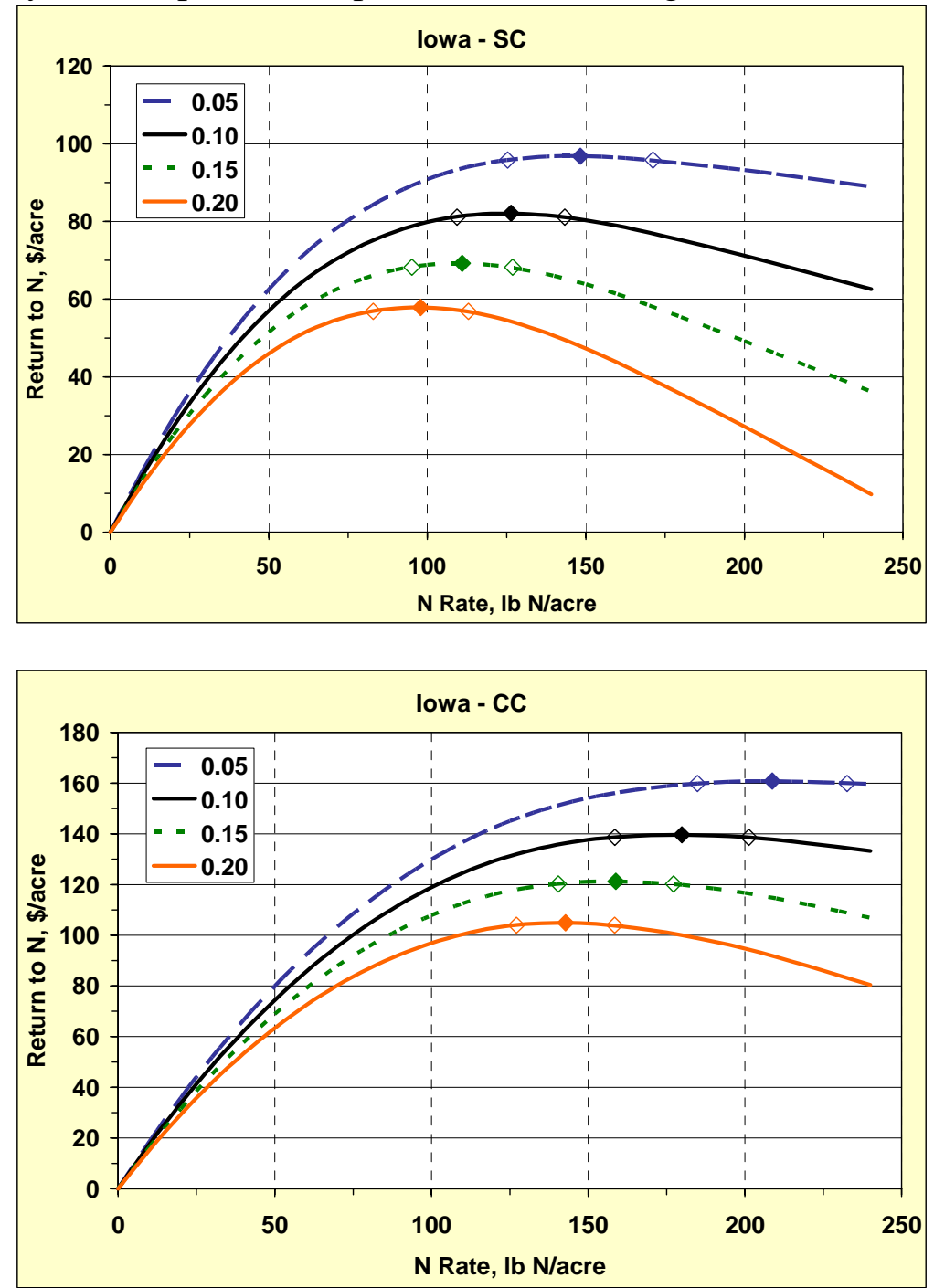
Figure 2. Relationship between corn grain yield and economic optimum $\mathrm{N}$ rate (EONR) for trial sites in Iowa with corn following soybean (SC), $0.10 \mathrm{~N}$ :corn grain price ratio.

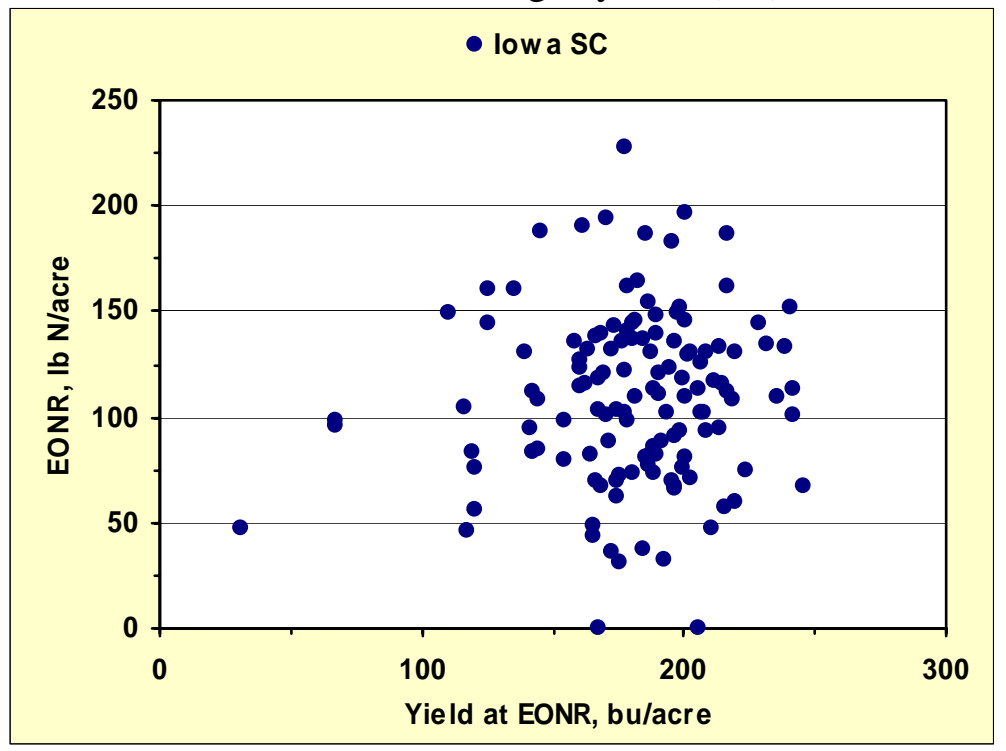

Figure 3. Tile-flow nitrate-N annual concentration average (corn following soybean, SC) from N rates applied in various years from 1990-2004 at the Gilmore City, IA water quality site and the net economic gain or loss ( $0.10 \mathrm{~N}$ :corn price ratio) across $\mathrm{N}$ rates for SC in Iowa. The solid black section of the net return line represents the economic gain if $\mathrm{N}$ rates are reduced to the maximum return to $\mathrm{N}$ (MRTN) rate, and the light (red) dashed section represents the economic loss if $\mathrm{N}$ rates are reduced below the MRTN rate. The indicated economic loss is for reduction of tile-flow nitrate- $\mathrm{N}$ from the MRTN rate to the $\mathrm{N}$ rate that results in approximately the $10 \mathrm{mg} / \mathrm{L} \mathrm{MCL}$ drinking water standard. Figure from Sawyer and Randall (2005).

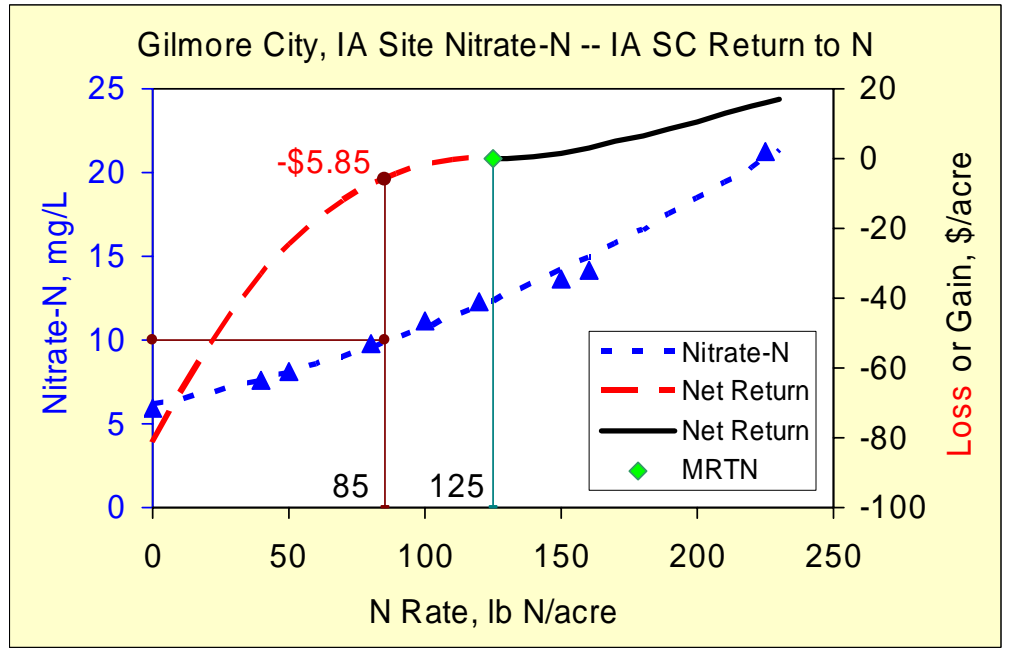


Figure 4. Nitrogen response for continuous corn (CC) and corn following soybean (SC) at seven $\mathrm{N}$ rate by crop rotation study sites (32-site-years) conducted at ISU research farms in Iowa, 2000-2005. Economic optimum $\mathrm{N}$ rate (EONR) and yield at the EONR calculated at a 0.10 $\mathrm{N}$ :corn price ratio.

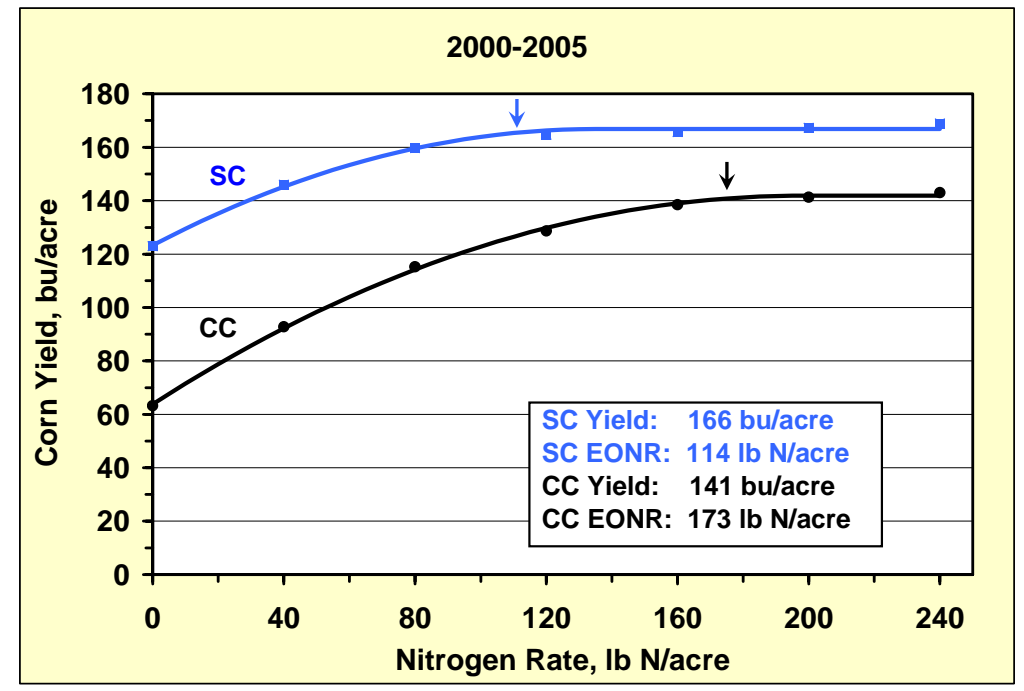

Figure 5. Average rotation and $\mathrm{N}$ fertilizer effects (2001-2004 period) on corn yield after 23 years at Nashua, IA (adapted from Mallarino et al., 2005). The letters a, c, and s refer to alfalfa, corn and soybean. The upper case " $\mathrm{C}$ " indicates the position in the crop rotation for the corn crop to which the $\mathrm{N}$ response curve refers.

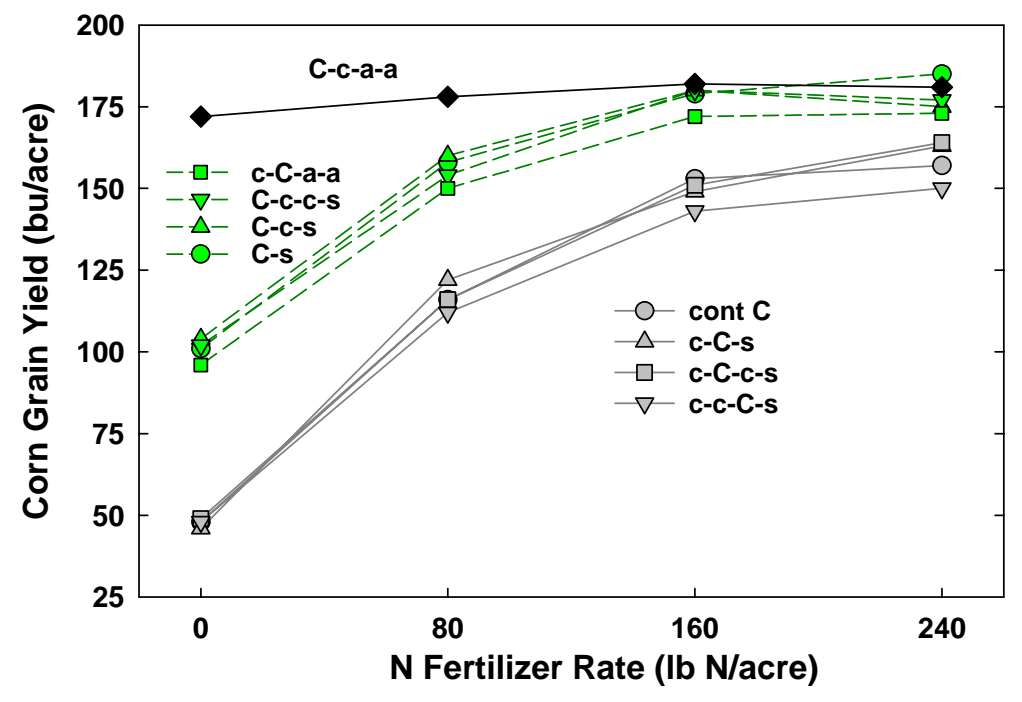

